\title{
David R. Oldroyd (1936-2014)
}

Many members of the IUGS community know David Oldroyd and will be sad to learn of his recent passing, age 78 years. Our President has written to Jane Oldroyd, and their sons, to express our sincere condolences.

David was born in Luton UK. He went up to Emmanuel College at Cambridge University. He was awarded a BA in Natural Science in 1958. Initially, he veered towards chemistry but was attracted to geology because he enjoyed the fieldwork. After leaving Cambridge, he worked as a school teacher in north London but emigrated to New Zealand in 1964, again to teach at schools, but, while there, registered for a MSc at University College, London, which he was awarded on the basis of a dissertation on "Geology in New Zealand prior to 1900" in 1967.

The history of geology thus became his passion. David soon relocated to the School of History and Philosophy of Science at University of New South Wales in Sydney, Australia where, as it turned out, he spent the rest of his career. There, he received his $\mathrm{PhD}$ for a thesis on "From Paracelsus to Haüy: the development of mineralogy in relation to chemistry" in 1974. Subsequently rising to Head of School and Professor, he was awarded a D.Litt in 1993, before retiring in 1996 as an Honorary Visiting Professor .

David was a Fellow of the Geological Society, London, and Australian Academy of the Humanities. He was also a Corresponding Member of the International Academy of History of Science as well as a Councillor of the History of Earth Sciences Society and a Councillor, and later, President of the Australasian Association for the History, Philosophy, and Social Studies of Science. But the IUGS community would have best known him as Secretary General of its Commission on the History of Geological Sciences (INHIGEO) from 1996-2004 and as Vice-President of that Commission for Australasia and Oceania from 2004-2012. He was also an INHIGEO Honorary Senior Member.

David was a prodigiously active author, editor and reviewer which amounted to some 62 refereed journal articles, 21 refereed essay reviews and book chapters, 37 encyclopedia articles, and 113 book reviews. He also

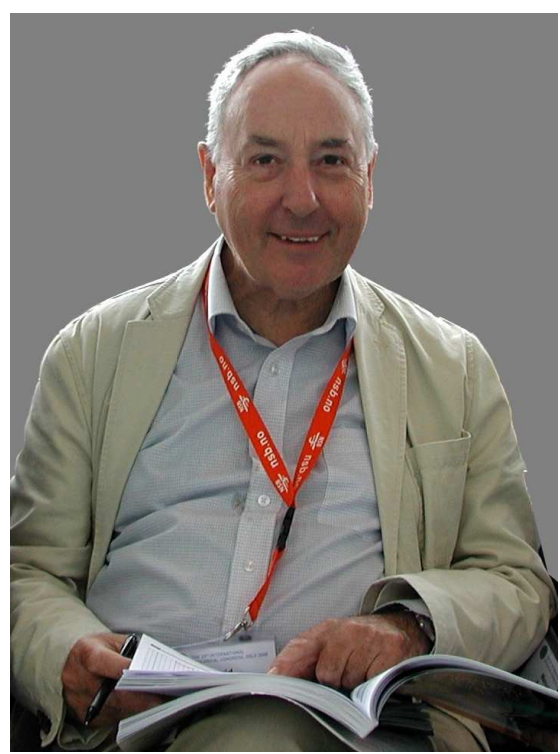

authored 6 books (which were widely translated) and edited 4 more. His editorial work involved journals, encyclopedias and dictionaries. He was the Editor of the journal "Earth Sciences History" from 2008-2013.

David's prizes and awards included the most outstanding paper from The Annals of Science (1990-1992), the Sue Tyler Friedman Medal of the Geological Society, London, for "distinguished contributions to the recording of the history of geology" (1994), the History of Geology Award of the Geological Society of America for "contributions of fundamental importance to our understanding of the history of the geological sciences" (1999) and the Tom Vallance Medal of the Geological Society of Australia (2014). This was capped by National Recognition by the Australian Commonwealth Government which deservedly awarded him a Centenary Medal, "for services to Australian society and the humanities in the study of the history of science" (2003).

David's books on the history of geology were diverse ranging from general reviews such as "The Highlands Controversy: Constructing Geological Knowledge through Fieldwork in Nineteenth-Century Britain" and "Thinking About the Earth: A History of Ideas in Geology" to more specific works such as "The Iconography of the Lisbon Earthquake". An internet search immediately confirms his contribution to our science as an author or editor. Those who knew David will mourn his passing but those who did not know him should go to the internet site: http://aahpasss.org/2014/11/09/vale-davidoldroyd.

There they will find an interview, in David's own words, typically modest and humorous, about his career and ideas, not least that those who engage in the history of geology should also do fieldwork to support their investigations. In the interview, he revealed that he entered the geosciences more by accident and design. It is very fortunate for our profession and for IUGS that he did and he will be sadly missed by many.

Following David Oldroyd's death, the INHIGEO Secretary General has received an exceptional number of written memories of him. Selected extracts from these reminisces follow. They tell much about David's kind character, intellectual acumen and generous contribution to the geosciences.

"The remembrance of David, his kindness, help and professional advice will always be in my heart"

"With whatever I have done for INHIGEO, he has been the spirit behind it. I will miss him a lot"

"He was a giant in the history of geology"

"David will be missed as a dear friend and an accomplished scholar"

"I was using his book 'Thinking about the Earth' when I received the INHIGEO email"

"He gave a lot to INHIGEO and I think it is difficult to imagine future INHIGEO meetings without him"

"a man with sweet humour and kind heart"

"It was always exciting to speak and correspond with him"

"David was not only a wonderful scholar but also a lovely, very generous man"

"It is difficult to think of INHIGEO without him"

"The scientific and organisational activity of this charismatic person is widely known." 